\title{
Recycling of Rainwater in a Social and Cultural Center ${ }^{+}$
}

\author{
Sofia Abrantes 1, Flora Silva 2,3,* and António Albuquerque 1,3 \\ 1 Department of Civil Engineering and Architecture, University of Beira Interior, Calçada Fonte do Lameiro, \\ 6201-001 Covilhã, Portugal; sofia.alexandra.abrantes@hotmail.com (S.A.); \\ antonio.albuquerque@ubi.pt (A.A.) \\ 2 School of Technology and Management, Polytechnic Institute of Bragança, Campus de Santa Apolónia, \\ 5300-253 Bragança, Portugal \\ 3 FibEnTech, Rua Marquês D' Ávila e Bolama, 6201-001 Covilhã, Portugal \\ * Correspondence: flora@ipb.pt; Tel.: +351-273-303-000 \\ + Presented at Environment, Green Technology and Engineering International Conference (EGTEIC 2018), \\ Caceres, Spain, 18-20 June 2018.
}

Published: 17 October 2018

\begin{abstract}
The potential reuse of rainwater in a Social and Cultural Center of Santo Aleixo (Unhais da Serra, Covilhã, Portugal) can reduce drinking water consumption up to $80.1 \%$ and can promote water savings of around $40,000.00 €$ in 20 years by combining the use of rainwater with the installation of hydraulically efficient equipment's.
\end{abstract}

Keywords: water reuse; rainwater; building networks; reduction of consumption; technical and economic feasibility

\section{Introduction}

Climate changes have influenced the variability of the hydrological regime around the world and there are still strong anthropogenic pressures over the water resources, which have led to changes in water resource management, namely considering water reuse as an alternative source of water [1]. The Portuguese National Program for the Efficient Use of Water (PNUEA) [2] for the urban sector intends to minimize the use of drinking water in activities that may have the same performance with alternative source of waters, namely the reuse of rainwater.

Rainwater harvesting is done by using pre-existing structures, and can be stored in reservoirs or cisterns and used with little or no treatment [3]. Rainwater harvesting systems (RHS) are made up of six basic components with very specific functions: catchment or collection surface, transport system, filtration, storage, distribution and treatment [4]. In Portugal, the installation and certification of a RHS, although is not to much applied, must comply with the established conditions in two technical specifications developed by the National Association for Quality in Buildings Installations (ANQIP): ETA 0701 [5] and ETA 0702 [6]. Due to the high billing of the drinking water consumption in the Social and Cultural Center of Santo Aleixo (SCCSA) (Unhais da Serra, Covilhã, Portugal), the main objective of this study was to find possible solutions for reducing the water consumption in the residential building. The technical and economic feasibility of four solutions was also analysed.

\section{Materials and Methods}

\section{Building Description and Solutions for the Reduction of Drinking Water Consumption}

The SCCSA is a Private Institution of Social Solidarity, consisting of a residential building (Figure 1a) with two floors and a building of new valences (Figure 1b), having in the surrounding 
area a garden with about $600 \mathrm{~m}^{2}$. It has 27 residents, 27 workers and 4 children in pre-school regime. In the 24 sanitary facilities there are 24 flushing cisterns ( $10 \mathrm{~L}$ reservoir), 2 of which have dual flushing mechanism and 32 conventional single-lever mixer taps $\left(9 \mathrm{~L} \mathrm{~min}^{-1}\right)$.

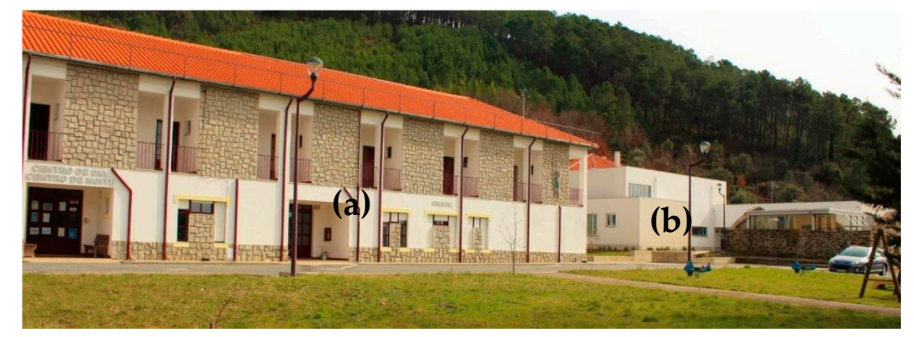

Figure 1. Social and Cultural Center of Santo Aleixo: (a) residential building; (b) building of new valences.

Two options were studied for the reduction of drinking water consumption in the building. The first option involved a scenario of replacement and modification of some equipment's, and the second one involved the study of three scenarios for the rainwater reuse [7] (Table 1).

Table 1. Proposed solutions for the reducing of drinking water consumption.

\begin{tabular}{|c|c|c|c|}
\hline \multirow{2}{*}{$\begin{array}{l}\text { Currently Installed } \\
\text { Equipment }\end{array}$} & \multicolumn{3}{|c|}{ Proposal of Changes } \\
\hline & \multicolumn{3}{|c|}{ Option 1: Replacement and Modification of Some Equipment's } \\
\hline \multirow{5}{*}{$\begin{array}{l}22 \text { single flushing } \\
\text { cisterns } \\
32 \text { conventional taps }\end{array}$} & \multicolumn{3}{|c|}{ Dual flushing cisterns with 6 L/3 L capacity } \\
\hline & \multicolumn{3}{|c|}{$\begin{array}{c}\text { Replacement of } 19 \text { conventional taps by temporized taps (ground floor) } \\
\text { Installation of flow reducers in } 13 \text { taps (1st floor) }\end{array}$} \\
\hline & \multicolumn{3}{|c|}{ Option 2: Rainwater reuse } \\
\hline & Scenario 1 & Scenario 2 & Scenario 3 \\
\hline & $\begin{array}{l}\text { Supplying of } \\
\text { the flushing } \\
\text { cisterns with } \\
\text { rainwater }\end{array}$ & $\begin{array}{l}\text { Supplying of the flushing } \\
\text { cisterns with rainwater, } \\
\text { replacing simple discharge } \\
\text { flushing cisterns by dual } \\
\text { flushing cisterns with } 6 \mathrm{~L} / 3 \\
\text { L capacity }\end{array}$ & $\begin{array}{l}\text { Supplying of the flushing cisterns } \\
\text { with rainwater, replacing simple } \\
\text { discharge flushing cisterns by } \\
\text { dual flushing cisterns with } 6 \mathrm{~L} / 3 \mathrm{~L} \\
\text { capacity and } \\
\text { replacement/modification of taps }\end{array}$ \\
\hline
\end{tabular}

For option 2, the recalculation of the building networks was done according to the Regulatory Decree no. 23/95, of August 23 [8] and Pedroso [9]. The supply with rainwater will come from a buried reservoir in a green area in front of the building, from where the water will be pumped into the water supply network. In the calculation of the reservoir volume for rainwater supply, only the water costs related to the cisterns were considered, since only these could be supplied with rainwater. Those costs were calculated taking into account the number of uses per inhabitant/day during 30 days. In total, it was considered a universe of 40 inhabitants [7]. A reservoir with $70 \mathrm{~m}^{3}$ (option 2: scenario 1) and 30 $\mathrm{m}^{3}$ (option 2: scenarios 2 and 3) would be suitable for the needs of the inhabitants [7].

\section{Results and Discussion}

\subsection{Technical and Economic Feasibility of the Solutions}

Regarding the technical feasibility, the two options considered for the reduction of drinking water consumption in the SCCSA can be implemented [7], from the constructive and sanitary hydraulic functioning point of view. In the rainwater supply building network, the flow velocities are within the suggested range $\left(0.5\right.$ and $\left.2.0 \mathrm{~m} \mathrm{~s}^{-1}\right)$ by [8,9] and the hydropressor group will guarantee the minimal pressures needed for the proper functioning of the equipment's. The economic feasibility study was made based on the volumes of water saved, the costs of investment, operation, maintenance, inspection, energy costs and returning time of the investment. 


\subsubsection{Reduction of the Volumes of Drinking Water}

Table 2 presents the values related to the average annual volume consumed, as well as the savings potential associated with each option.

Table 2. Average annual volumes of water consumed and savings potential.

\begin{tabular}{cccccc}
\hline \multicolumn{3}{c}{ Average Annual Volumes of Drinking Water Consumed (m $\mathbf{~}^{\mathbf{3}}$} \\
\hline & $\begin{array}{c}\text { Current } \\
\text { Consumption }\end{array}$ & Option 1 & \multicolumn{3}{c}{ Option 2 } \\
\cline { 4 - 6 } & & Scenario 1 & Scenario 2 & Scenario 3 \\
\hline Flushing cisterns & 792 & 285.12 & 228.7 & 39.9 & 39.9 \\
Taps & 285.12 & 174.24 & 285.12 & 285.12 & 174.24 \\
Total & 1077.12 & 459.36 & 513.8 & 325.0 & 214.1 \\
\hline Savings (\%) & 0 & 57.4 & 52.3 & 69.8 & 80.1 \\
\hline
\end{tabular}

According to Table 2, the scenario 1 of the option 2 is the one with the higher water consumption, achieving savings of $52.3 \%$. The scenario 3 of the option 2 would lead to greater saving of drinking water $(80.1 \%)$.

\subsubsection{Return of the Investments}

The time needed to recover the investment in the SCCSA was determined by taking into account the total investment value, maintenance costs every 10 years, savings in water billing, urban waste management and sanitation costs [7]. Initial investment costs include the costs associated with the installation of the rainwater supply building network, the installation of building drainage pipes and rainwater drainage building network inspection boxes, the excavation associated with the installation of the reservoir, the installation of network elements, equipment, hydropressor group, accessories and manpower. Applying the current tariffs at the municipality of Covilhã [10] and considering the saved volume of water and the average rainfall relative to each month, from January 2001 to August 2017 [11], the average monthly and annual savings were determined, in relation to the billing of water, sanitation and municipal solid waste services for the two options. Table 3 shows the average annual savings and the return time of the investment, which is also shown in the Figure 2.

Table 3. Average annual savings and return time of the investment.

\begin{tabular}{lcccc}
\hline & \multirow{2}{*}{ Option 1 } & \multicolumn{3}{c}{ Option 2 } \\
\cline { 3 - 5 } & & Scenario 1 & Scenario 2 & Scenario 3 \\
\hline Initial investment $(€)$ & $5520.00 €$ & $30,975.08 €$ & $24,172.12 €$ & $25,895.08 €$ \\
Maintenance costs in 10 years $(€)$ & $0.00 €$ & $2256.00 €$ & $2256.00 €$ & $2256.00 €$ \\
Average annual savings $(€)$ & $2357.13 €$ & $2149.27 €$ & $2869.87 €$ & $3292.95 €$ \\
Return time of the investment (years) & 3 & 15 & 9 & 8 \\
\hline
\end{tabular}

After analysing the results (Table 3), the scenario 3 of the option 2 is the most favourable concerning water saving and associated billing costs [7]. From the analysis of the Figure 2, it is possible to verify that for the same scenario, within a period of 20 years, savings of around $40,000.00$ $€$ can be achieved. 


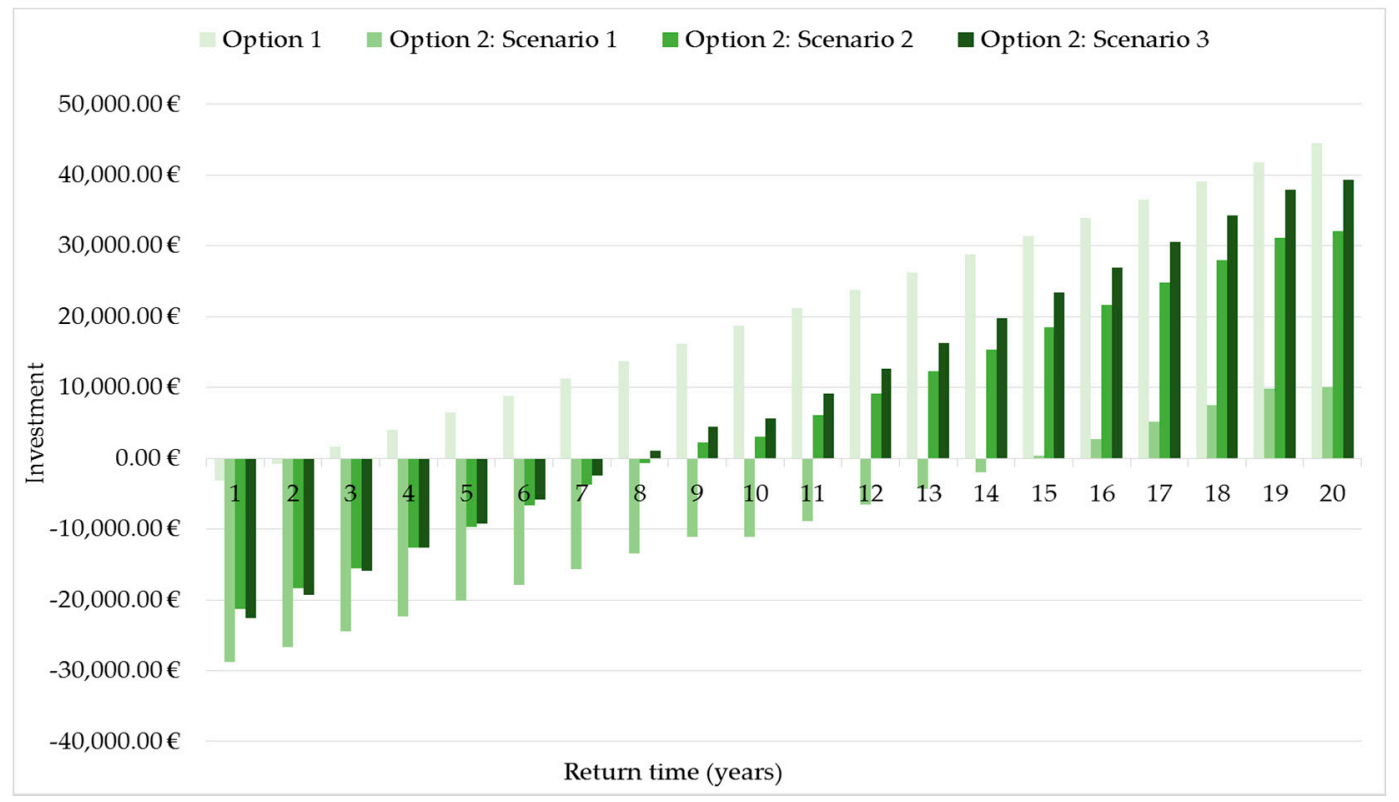

Figure 2. Return time of the investment.

\section{Conclusions}

This study showed that reusing rainwater in a social and cultural center, associated to the replacement and modification of existent sanitary equipment's, can lead to water consumption reductions of $80.1 \%$ and savings of around $40,000.00 €$ in 20 years. The turnover of the investment will be achieved in 8 years.

Author Contributions: The work was performed by S.A. during her MSc Dissertation, and supervised by F.S. and A.A.

Conflicts of Interest: The authors declare no conflict of interest.

\section{References}

1. Marecos do Monte, H.; Albuquerque, A. Reutilização de Águas Residuais; Technical Guide No.14.; ERSAR: Lisbon, Portugal, 2010. (In Portuguese)

2. Agência Portuguesa do Ambiente. Programa Nacional para o Uso Eficiente da Água (PNUEA). APA, 2012. Available online: http://www.apambiente.pt/ (accessed on 3 July 2017). (In Portuguese)

3. Lamberts, R.; Ghisi, E.; Pereira, C.; Batista, J. Casa Eficiente: Uso racional da água. Florianopolis: UFSC/LabEEE, 2010, Volume 3. Available online: http://www.labeee.ufsc.br/ (accessed on 10 August 2017). (In Portuguese)

4. Texas Water Development Board. The Texas Manual on Rainwater Harvesting, 3th ed.; Texas Water Development Board: Austin, TX, USA, 2005. Available online: http://www.twdb.texas.gov/ (accessed on 10 August 2017).

5. ANQIP. ETA 0701, 2013. Available online: http://www.anqip.pt/ (accessed on 10 August 2017). (In Portuguese)

6. ANQIP. ETA 0702, 2013. Available online: http://www.anqip.pt/ (accessed on 10 August 2017). (In Portuguese)

7. Abrantes, S. Avaliação do potencial de reutilização de águas no Centro Social e Cultural de Santo Aleixo em Unhais da Serra. Master's Thesis, University of Beira Interior, Covilhã, Portugal, 2017. (In Portuguese)

8. Decreto Regulamentar No. 23/95 de 23 de Agosto; Portuguese Regulatory Decree: Lisbon, Portugal, 1995.

9. Pedroso, V. Manual dos Sistemas Prediais de Distribuição e Drenagem de Águas, 6th ed; LNEC: Lisbon, Portugal, 2016. (In Portuguese) 
10. Águas da Covilhã. Available online: http://www.aguasdacovilha.pt/ (accessed on 10 September 2017).

11. SNIRH. Available online: http://snirh.apambiente.pt/ (accessed on 10 September 2017).

(C) 2018 by the authors. Licensee MDPI, Basel, Switzerland. This article is an open access article distributed under the terms and conditions of the Creative Commons Attribution (CC BY) license (http://creativecommons.org/licenses/by/4.0/). 